\title{
ETURISTIRIIDAT JA SUUNNITTELU MAUNO KOIVISTON YHTEISKUNTAPOLITIIKASSA ${ }^{1}$
}

\author{
Pauli Kettunen \\ professori, Helsingin yliopisto
}

\section{Väärää politiikkaa}

Sadekesänä 1977 Mauno Koivisto kokosi muistiinpanoistaan, kirjoituksistaan, puheistaan ja esitelmistään kirjan, jolle hän antoi otsikon Väärää politiikkaa. Ne, jotka syyttivät politiikkaa ja erityisesti talouspolitiikkaa vääräksi, olivat silloisen Suomen Pankin pääjohtajan mielestä "huomattavan naiiveja". Sillä "talouspolitiikkahan on aina väärää, kysymys on vain siitä, kenen kannalta ja miltä kannalta". Suhdannepoliittiset toimet saattoivat olla vääriä rakennepoliittisesti ja aluepoliittiset vääriä suhdannepoliittisesti. "Mutta vaikka talouspolitiikka periaatteessa aina onkin väärä, on silti pyrittävä siihen, että se olisi kokonaisuutena ottaen mahdollisimman vähän väärää, ja että tärkeimpinä pidetyt talouspoliittiset tavoitteet tulisivat tavoitetuiksi vähemmän tärkeiden kustannuksella."2

"Väärää politiikkaa" -otsikon perusteluista voi lukea kolme puolta siitä, mitä voidaan pitää Mauno Koiviston yhteiskuntapoliittisena perintönä. Ensimmäinen sisältyi kysymykseen siitä, "kenen kannalta" politiikka oli väärää: oli tunnustettava, että yhteiskunnassa oli erilaisia, ristiriitaisia etuja. Toisen tärkeän piirteen osoitti kysymys, "miltä kannalta" se oli väärää: oli tunnustettava, että yhteisetkin tavoitteet olivat usein keskenään ristiriitaisia. Kolmas tuli esiin toteamuksessa siitä, että väärän po- litiikan oli "kokonaisuutena ottaen" hyvä olla mahdollisimman vähän väärää: oli koetettava saada aikaan kompromisseja eri etujen välille ja koetettava hallita eri osa-alueiden politiikkojen tarkoittamattomia seurauksia. Tarkastelen tässä esityksessäni tätä Koiviston näkemystä, jonka hän käsitykseni mukaan jalosti omista kokemuksistaan sekä yhteiskuntatieteilijänä että poliittisena toimijana. Suhteutan sitä Suomessa toisen maailmansodan jälkeen tapahtuneisiin muutoksiin siinä, miten yhteiskunnallisten ristiriitojen käsittelyä ja yhteiskuntapoliittista suunnitelmallisuutta ajateltiin ja yhdistettiin.

\section{Hyvinvointivaltio}

\section{- yhteinen kansallinen projekti?}

Koiviston Väärää politiikkaa kyseenalaistaa yhden nykyisin julkisessa keskustelussa suositun historiantulkinnan - kuvan hyvinvointivaltion rakentamisesta suunnitelmallisena yhteisenä kansallisena projektina. Hyvinvointivaltio ei ollut Suomessa yhtä suunnitelmallinen projekti kuin Ruotsissa, vahvemman sosialidemokratian maassa, ja yhteinen kansallinen projekti se ei ollut kummassakaan. Käytännöt ja rakenteet, joita kutsumme hyvinvointivaltioksi, syntyivät ristiriidoista, kompromisseista ja usein myös toiminnan tarkoittamattomista seurauksista, ja niitä tarkoittavana käsitteenä 


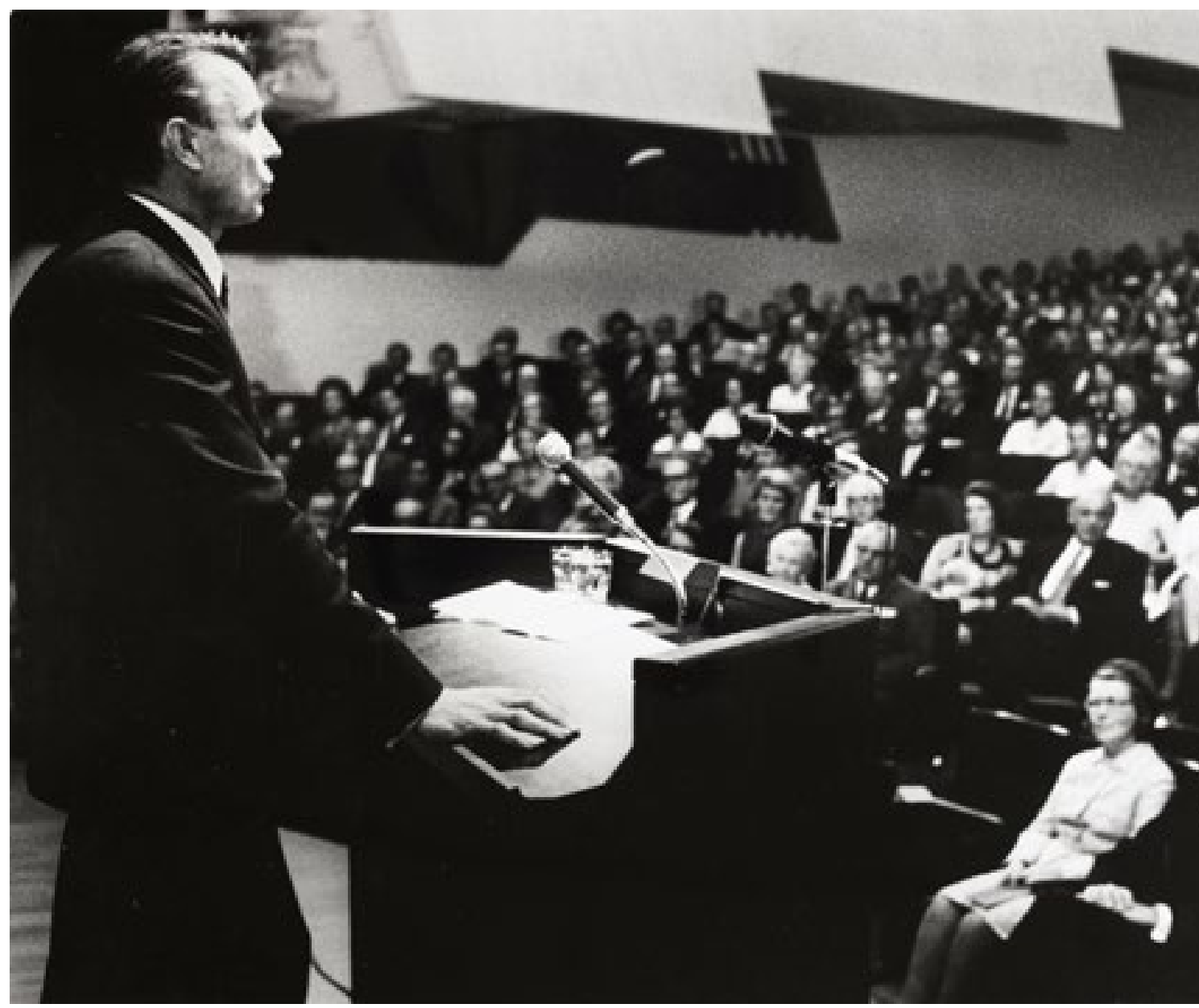

Mauno Koivisto puhumassa Finlandia-talossa 1970-luvulla. Kuva:Työväen Arkisto.

"hyvinvointivaltio" yleistyi toden teolla vasta niiden jouduttua uhatuiksi. ${ }^{3}$

Asian toinen puoli on se, että poliittista kamppailua kehysti Suomessa vahvasti sisäistetty ajattelutapa, joka vaati kansallisten välttämättömyyksien tunnistamista ja tunnustamista. Politiikka on näyttänyt olevan lähimpänä ihannettaan, kun lujalla sisäisellä tahdolla on vastattu ulkoisiin välttämättömyyksiin ja tehty se, mikä on ollut pakko tehdä. Tälle ajattelutavalle oli pohjaa sekä menneen kokemuksissa että tulevan odotuksissa. Se oli tulkinta Suomen kansainvälispoliittisesta asemasta, siitä mitä sotien kokemukset ja niiden jälkeinen tilanne edellyttivät suhteessa Neuvostoliittoon. Ulkoisten välttämättömyyksien korostus liittyi myös Suomen asemaan kansainvälisessä taloudessa. Vientiteollisuudella oli erityinen voima esittää omat etunsa kansallisina etuina ja välttämättömyyksinä, sillä sen kehitys vaikutti metsien välityksellä laajasti ja konkreettisesti sosioekonomiseen ja alueelliseen rakenteeseen.

Lisäksi tuli suomalaisen yhteiskunnan muutosrytmi: rakennemuutokset alkoivat myöhään, mutta tapahtuivat nopeasti. Nämä muutokset kohdattiin kansallisina välttämät- 
tömyyksinä, joihin oli reagoitava, kuten on reagoitu myös sodanjälkeisten suurten ikäluokkien vaellukseen kehdosta kouluun, työelämään ja eläkkeelle.

Yhteiskunnalliset uudistukset sidottiin toisen maailmansodan jälkeen taloudellisen kasvun välttämättömyyteen, useimmiten niin, että kasvun katsottiin luovan resurssit ja rajat uudistuksille. Välttämättömyyden sanomaa julistivat kuitenkin myös ne, jotka kehittelivät näkemystä siitä, että sosiaalinen tasoitus on keino vahvistaa taloudellista kasvua. Vuonna 1961 julkaistua Pekka Kuusen teosta 60-luvun sosiaalipolitiikka luonnehditaan usein suomalaisen hyvinvointivaltion suunnitelmaksi. Kuusi itse karttoi käsitettä hyvinvointivaltio, ja hänelle kyse olikin enemmästä, kansakunnan eloonjäämisestä: "Jos mielimme Ruotsin ja Neuvostoliiton, kahden kasvutietoisen ja -kykyisen kansan, välissä jatkaa omaa elämäämme, me olemme tuomitut kasvamaan.” Se, mikä oli välttämätöntä, oli kuitenkin myös mahdollista: "Kansanvalta, sosiaalinen tasoitus ja taloudellinen kasvu näyttävät nyky-yhteiskunnassa kytkeytyvän onnellisella tavalla toisiinsa." ${ }^{4}$

Kaikki eivät jakaneet Kuusen arviota sosiaalipolitiikan merkityksestä talouskasvulle, kuten Erkki Tuomiojan Kuusi-väitöskirjasta voi lukea. Kuusen argumenttia kiittivät kuitenkin arvosteluissaan Mauno Koivisto ja Olavi Niitamo. ${ }^{5}$ He kumpikin kuuluivat ns. O-ryhmään, 1950-luvun puolivälissä muotoutuneeseen keskustelupiiriin, joka ajoi suomalaisen taloustieteen uudistamista ja talouspolitiikan rationalisoimista. ${ }^{6}$ Kuusen suunnitelman jälkeenkin monien oli kuitenkin vaivattomampaa perustella kansallisina välttämättömyyksinä muutoksiin reagoivia kompromisseja kuin niiden suunnitelmallista yhteiskuntapoliittista ohjaamista. Toisaalta Kuusen tavassa korostaa hyvien tavoitteiden yhteensopivuutta ja yhteiskuntapolitiikan yhteisiä tavoitteita oli sellaista, mikä näyttää poikenneen tavoitteiden ristiriitaisuuden tunnustaneen Koiviston ajattelusta.

\section{Yhteiskuntapolitikka}

Talouspolitiikan ja sosiaalipolitiikan keskinäissuhteiden pohdinta edisti käsitteen "yhteiskuntapolitiikka" uutta, laajaa käyttötapaa - aiemmin se oli ollut sosiaalipolitiikan synonyymi. Kuuselle sosiaalipolitiikka oli yksi yhteiskuntapolitiikan komponentti, ja sen oli toteutettava yhteiskuntapolitiikan yleisiä tavoitteita. "Yhteiskuntapolitiikka" viittasi eri politiikkalohkojen rationaaliseen koordinointiin myös Koiviston aloitteesta vuoden 1961 lopussa perustetun Yhteiskuntapoliittisen sos. dem. yhdistyksen nimessä.

Yhteiskuntapolitiikkaansa Koivisto luonnehti esimerkiksi kirjallisuuslehti Parnassossa ensimmäisen pääministerikautensa lopulla vuoden 1970 alussa. Pitkässä kirja-arviossaan Yrjö Ahmavaaran Yhteiskuntatieteen kyberneettisestä metodologiasta ${ }^{7}$ hän kuvasi vuonna 1966 alkanutta vasemmistoenemmistöisen eduskunnan ja hallituksen aikaa: "Kohta neljän vuoden ajan on valtiojohtoisessa yhteiskuntapolitiikassa ollut vallalla asennoituminen, joka vielä jokin aika sitten edusti uutta suuntausta: ennustuksiin perustuvaa suunnittelua, ennusteiden ja suunnitelmien jatkuvaa tarkistamista, taloudellisen kasvun avulla suoritettavaa yhteiskunnallista ongelmien ratkaisuyritystä, ryhmätyötä, kokonaistarkastelua, nippu- ja ketjuratkaisuja.” Tämä asennoituminen oli syntynyt "oppositioliikkeenä niitä vastaan, jotka ilman tutkimuksiakin tiesivät mikä oli kulloinkin totuus" ja jotka "kavahtivat kaikkea suunnittelua". Se oli syntynyt "reaktiona osittaisratkaisuja vastaan, erilaisten tavoitteiden erillispainottamista vastaan, otettujen sosiaalisten edistysaskeleiden ajoittaisia purkamisoperaatioita vastaan".

Kirjoituksen keskeisiä näkökohtia oli määrällisen kasvun kritiikki, mikä osoitti Koiviston perehtyneen ajankohtaiseen kansainväliseen keskusteluun kasvun rajoista. Ahmavaaran teos oli hänen mielestään "arvokas apuväline, arvokkain tuntemistani" sellaisessa tilanteessa, 
jossa oli hylättävä henkistä pahoinvointia lisäävä ja umpikujaan johtava "pelkän määrällisen kasvun tie" ja suuntauduttava "laadullisen kasvun ja muutosten tielle". Tämä vaati "määrätietoista yhteiskuntapolitiikkaa", ja sitä "ei voi olla ilman ideologiaa, ei ilman filosofiaa, ei ilman tutkimusta”. Ahmavaaran ajatusta vallankumouksellisesta yhteiskuntatieteestä Parnasson kriitikko ei niellyt, mutta pitkään pohdintaan häntä inspiroi marxilaisen kyberneetikon toteamus, jonka mukaan "(v)allankumouksellisen yhteiskuntatieteen tärkeimpänä tehtävänä on kumulatiivisten prosessien ohjaus kohti vallankumouksellista tilannetta”.

Näkemys yhteiskunnallisista muutoksista kumulatiivisina, itseään vahvistavina prosesseina oli keskeinen 1960-luvun yhteiskuntapoliittisessa kehittelyssä. Kuusen suunnitelman innoittajiin kuului ruotsalainen sosialidemokraattinen taloustieteilijä ja yhteiskuntateoreetikko Gunnar Myrdal. "Kumulatiivisen kausaation" teoriassaan Myrdal tarkasteli yhteiskunnallisia muutoksia ja maailmanlaajuista kehityksen ja alikehityksen dynamiikkaa itseään vahvistavina kehinä, joilla taloudelliset, sosiaaliset ja kulttuuriset tekijät kietoutuivat toisiinsa. ${ }^{8}$ Kehät olivat usein noidankehiä, köyhyyttä ja huono-osaisuutta kasaavia prosesseja, mutta yhteiskunnallisella suunnitelmallisuudella ne voitiin kääntää hyviksi kehiksi. Tällainen toisiaan tukevien tavoitteiden hyvä kehä yhdistäisi sosiaalista tasoitusta, demokratian laajentamista ja talouskasvua, kuten Pohjoismaissa, muissa enemmän kuin Suomessa, näytti jo tapahtuneen.

Myrdal kehitteli Kuusen kirjan ilmestymisen aikoihin visiota, jonka mukaan suunnittelun täydellistyessä sen valtiokeskeisyys vähenisi. Valistuneet kansalaiset toisivat omien järjestöjensä kautta intressinsä suunnittelun voimaksi, siinä yhteen sovitettaviksi. Kaikki relevantit intressit tuotaisiin mukaan, eikä kukaan voisi väittää omaa etuansa yleiseksi eduksi. Näin rakentuisi "luotu harmonia" (created harmony) vastakohtana katteettomalle oletukselle markkinoiden luomasta spontaanista tasapainosta. $^{9}$

Kuusen suhde etujärjestöihin, myös ammattiyhdistysliikkeeseen, oli etäinen. Koiviston yhteiskuntapoliittisessa ajattelussa taas erilaisilla eduilla oli olennainen sija. Etuja oli sovitettava ja kompromisseja tehtävä. Myrdalilaista luodun harmonian ideaa Koivistolta ei kuitenkaan löydä. Esimerkiksi puhuessaan Jyväskylän kulttuuripäivillä 1965 hän oletti, ”että kaikenmuotoisissa tulevaisuudenkin yhteiskunnissa muutoksiin johtavaa kehitystä ajavat eteenpäin yhteiskunnassa vaikuttavat voimat ja vastavoimat, jotka edustavat lähinnä eri suuntiin käyviä etuja, intressejä”. Ristiriitaisiin etuihin perustuva erimielisyys saattoi kuitenkin ilmetä "kovin monella eri tietämyksen tasolla, niin karkeasti kuin kultivoidustikin" ${ }^{10}$ Tarkasteltaessa Koiviston suhdetta yhteiskunnallisiin ristiriitoihin on tärkeätä kiinnittää huomiota siihen, miten sota-ajan tehtävät ja kokemukset vaikuttivat sodanjälkeisiin tapoihin hahmottaa yhteiskunta tiedon ja politiikan kohteeksi.

\section{Ristiriidat}

Sota-ajan poikkeusoloissa vahvistui näkemys yhteiskunnasta työnjaollisena, funktionaalisena kokonaisuutena, jota oli pakko suunnitella ja ohjata. Tähän liittyi se, että rationalisointi nostettiin välttämättömäksi kansalliseksi tehtäväksi. Niin sotatoimissa kuin kotirintamalla yksilöiden sovittaminen ja sopeuttaminen tämän kokonaisuuden tehtäviin koettiin uudella tavalla pakottavaksi ongelmaksi. Rationalisoitavan yhteiskunnan ja sopeutettavan yksilön lisäksi sota-aikana hahmottui kuitenkin myös ongelmataso yksilön ja yhteiskunnan välissä: sosiaalinen ryhmänmuodostus. Sotilaselämässä vaikuttivat virallisen organisaation ja virallisten normien rinnalla perin erilaiset epäviralliset organisoitumismuodot ja normit. Epävirallinen normisto ilmeni ohjeiden kiertämisenä, esimiesten valvovan katseen välttelemisenä ja 
purnaamisena. Se osoittautui kuitenkin tarpeelliseksi organisaation toimintakyvylle, kuten sotilaidensa kunnioituksen saavuttaneet upseerit jo tuolloin tunnustivat ja kuten Väinö Linna Tuntemattomassa sotilaassa (1954) ja Knut Pipping sosiologisessa väitöskirjassaan (1947) kuvasivat. ${ }^{11}$

Ne sosiologit, jotka sotien jälkeen ryhtyivät tutkimaan työelämän suhteita, Mauno Koivisto yhtenä heistä, olivat sodan käyneitä miehiä. Vuonna 1955 väitellyt Paavo Koli kertoi saaneensa alkukipinän työelämän tutkimiseen sotilaselämän hämmennyksestä: "Käyttäytyminen näytti tapahtuvan käsittämättömiä lakeja seuraten, tuntemattomien tekijöiden säätäessä ryhmätoimintojen kulkua." 12

Suomalaisen työn sosiologian ensimmäistä aaltoa yhdisti näkemys ristiriidoista rakenteellisena yhteiskunnallisena tosiasiana, joka ei palautunut poliittiseen kiihotukseen, vaan vaati sosiologista selitystä. Koivistolla oli vahvat omakohtaiset kokemukset taistelusta kommunisteja vastaan satamissa, mutta väitöskirjassaan vuodelta 1956 hän selitti Turun sataman riitaisia sosiaalisia suhteita satamatyön luonteen ja traditioiden pohjalta. Hän arveli työriitojen olevan hinta, joka oli maksettava työmarkkinoiden ja yhteiskunnan vapaudesta. Työnantajille oli hänen käsittääkseen tarjolla käyttämättömiä keinoja parantaa työpaikan sosiaalisia suhteita, mutta ristiriidat eivät silti häviäisi. Hän piti vieläpä mahdollisena, ettei työnantajien ja työntekijöiden välien paraneminen olisi aina kaikin puolin toivottua, sillä näiden ryhmien hyvä yhteistyö saattoi joskus koitua esimerkiksi asiakkaiden ja kuluttajien vahingoksi. Eivätkä ristiriidat tehneet elämistä mahdottomaksi: "Vaikka Turun satamassa jatkuvasti riidellään, se ei tässä levottomuuden ja epävarmuuden täyttämässä maailmassa liene mikään erikoisen onneton paikka ..."13

Sosiologia nousi 1960-luvulla kansallisen integraation tieteeksi. Sosiologi Erik Allardt erotteli neljä suomalaisen yhteiskunnan perusvastakohtaisuutta. Ensimmäisessä olivat vastakkain suomenkieliset ja ruotsinkieliset, toisessa maalaiset ja kaupunkilaiset, kolmannessa työväestö ja porvaristo ja neljännessä kommunistit ja kaikki muut. Viimeksi mainittu - kommunistien vaarallinen eristyneisyys - oli kansallisen integraation ajankohtaisin ongelma. Allardt totesi Émile Durkheimin tuella, että pitkälle kehittyneen työnjaon yhteiskunnassa yhdenmukaisuuden painetta oli alennettava yhteiskunnan toimintakyvyn ja kiinteyden nimissä. Ralf Dahrendorfin ajatuksia soveltaen hän päätteli tämän tarkoittavan yhteiskunnallisten ristiriitojen tunnustamista ja sääntelemistä. ${ }^{14}$ Tätä näkemystä vastasivat kommunistien tulo hallitukseen vuonna 1966 - Koiviston aktiivisella myötävaikutuksella ja tulopoliittisen sopimusjärjestelmän rakentaminen - Koiviston ensimmäisen valtiovarainministerikauden ja ensimmäisen pääministerikauden saumakohdassa.

Koiviston ajattelussa tärkeä pysyvä sija näyttää olleen käsityksellä, jonka mukaan ristiriidat kävivät vaarallisiksi, jollei niitä tunnustettu. Ristiriitojen poistamistakin hän piti huonona ajatuksena. Vuoden 1982 alussa presidenttiehdokas Koivisto vastasi hänen sosialisminsa laatua tivanneelle Helsingin Sanomien haastattelijalle: "Ajatus ristiriitojen poistamisesta on sillä tavoin vaarallinen, että kun arkista konfliktia tarpeeksi poistetaan, niin saadaan jättiläiskonflikti.” Hän torjui marxilais-hegeliläiseksi luonnehtimansa oletuksen historian lainalaisuuksista, jotka johtaisivat ristiriidattomaan yhteiskuntaan ja joiden toteuttajiksi jotkut - kommunistit, itse asiassa pitkään myös sosialidemokraatit - itsensä kohottivat. ${ }^{15}$

Torjuessaan ristiriitojen poistamisen Koivisto näyttää kuitenkin ottaneen etäisyyttä myös suomalaiskansalliseen yhtenäisyyden vaatimukseen. Kansakunnan rakentamisen vaiheessa 1800 -luvulla ajatus yhtenäisestä kansasta tuli keskeiseksi politiikan perusteluksi. Paradoksaalisesti se pohjusti myös kärkeviä ristiriitoja: konsensusideaalin pohjalta poliittiset kiistat muodostuivat helposti taisteluiksi 
siitä, kenellä oli oikeus puhua kansan nimissä ja siten määritellä kansa. Vuoden 1918 sisällissodankin taustalla voi nähdä tällaisen vastakkainasettelun. Samalla kun kansallisen yhtenäisyyden ideaali saattoi ruokkia ristiriitoja, se antoi vahvoille valtaa esittää omat etunsa ja näkemyksensä yleisinä etuina ja yleispätevinä näkemyksinä. Koiviston käsitys kansallisesta toimijuudesta poikkesi selvästikin tällaisesta yhtenäisyyden ideaalista. Hänen yhteiskuntapolitiikkaansa kuului yhteiskunnallisten valtasuhteiden tasoitus siten, että niiden heikommat osapuolet saivat voimaa omien tarpeidensa ja etujensa edistämiseen.

\section{Mahdollisimman vähän väärää politiikkaa}

Vä̈rää politiikkaa -kirjan perusteluissa Koivisto tuli ilmaisseeksi epäluulonsa niitä kohtaan, jotka katsoivat edustavansa oikeata politiikkaa. Hänen näkemyksessään tulevaisuus oli epävarma, avoin ja kiistanalainen. Sitä tehtiin poliittisesti eri etujen ja tavoitteiden kompromissien tietä. Tavoitteellisen toiminnan tarkoittamattomia seurauksia oli koetettava hallita rationaalisella yhteiskuntapolitiikalla, joka perustui empiiriseen tietoon. Yhteiskuntapolitiikalla murrettiin noidankehiä ja torjuttiin vaarallisia konflikteja, mutta ennalta määritellyn totuuden toteuttamista se ei ollut, eikä olevien olojen kritisoinnin mittapuuna ollut harmonian ideaali.

Viimeisessä valtiopäivien avajaispuheessaan helmikuussa 1994 tasavallan presidentti
Koivisto totesi, että ulkopolitiikassa oli "syytä pyrkiä yhtenäiseen esiintymiseen ja korostaa jatkuvuutta". Hallituksen osuutta oli kuitenkin vahvistettava erityisesti siksi, että yhdentyvässä Euroopassa ratkaistavilla asioilla oli "yleistä yhteiskuntapoliittista merkitystä" paljon yli perinteisen ulkopolitiikan alueen. Sisäpolitiikassa presidentin ei pitänyt olla aktiivinen: "Mehän elämme moniarvoisessa yhteiskunnassa." Oli parempi, "että eri henkilöt edustavat erilaisia arvoja ja tavoitteita ja sovittelevat niistä lähteviä pyrkimyksiä keskenänsä, kuin että tällainen punninta tulisi tapahtumaan yhden henkilön sisällä”. ${ }^{16}$

Maaliskuun 1. päivänä 1994, tasavallan presidentin vaihtuessa, Koivisto puhui viimeistä kertaa eduskunnalle. Jälleen kerran hän arvioi myös tieteen ja tutkimuksen suhdetta politiikkaan. Hän oli vakuuttunut, että "järjestelmällisiin havaintoihin perustuva, ilmiöiden keskinäisiä syy- ja seuraussuhteita selvittävä talouspolitiikka antaa varmemmin haluttuja tuloksia kuin pelkästään henkilökohtaiseen kokemukseen rakentuva”. Politiikka oli kuitenkin hänen mukaansa "paitsi tiedon asia myös tahdon asia, ja ennen kaikkea se on osaamisen asia”. Häneltä ei tullut tukea oletuksille, joiden mukaan oikea tieto hävittäisi ristiriidat. Jo puheensa alussa Koivisto toisti näkemyksensä ristiriitojen pysyvyydestä: "Meillä on kansakuntana yhteisesti tavoiteltavia asioita, mutta meillä on myös poikkeavia käsityksiä ja vaikeasti yhteensoviteltavia, ristiinkäyviä etuja. Näin on oleva vastaisuudessakin." ${ }^{17}$

\section{Viitteet}

1 Kirjoitus perustuu esitelmään Mauno Koiviston perintö kantaa -juhlaseminaarissa Helsingin työväentalolla 25.11.2017.

2 Koivisto, Mauno 1978. Väärää politiikkaa. Helsinki, Kirjayhtymä, 7-9.

3 Olen perustellut tätä tulkintaa mm. kirjoituksissani Kettunen, Pauli 2015: Hyvinvointivaltion yhteiskunta. Teoksessa Autto, Janne \& Nygård, Mikael (toim.) Hyvinvointivaltion kulttuurintutkimus. Rovaniemi, Lapin yliopistokustannus, 71-109, ja Kettunen,
Pauli 2019: The Conceptual History of the Welfare State in Finland. Teoksessa Edling, Nils (toim.) The Changing Meanings of the Welfare State. Histories of a Key Concept in the Nordic Countries. New York \& Oxford, Berghahn, 225-275. - Kun suomalaiset sosialidemokraatit luonnehtivat 1960-luvulla tavoitettaan hyvinvointivaltioksi, käsite viittasi useimmiten ihmisten hyvinvoinnin yleiseen lisäämiseen pikemmin kuin valtion tehtävien uuteen määrittelyyn. Mauno Koivisto kuului niihin muutamiin "teoreettisten kysy- 
mysten harrastajiin", joita kiinnosti hyvinvointivaltion ja sosialismin suhde; esim. Koivisto, Mauno 1968. Vasemmiston yhteistyön edellytykset. Teoksessa Linjan vetoa. Helsinki, Kirjayhtymä, 42 (lainaus teoksesta).

4 Kuusi, Pekka 1961. 60-luvun sosiaalipolitiikka. Porvoo, WSOY, 8, 34.

5 Tuomioja, Erkki 1996. Pekka Kuusi. Alkoholipoliitikko, sosiaalipoliitikko, ihmiskuntapoliitikko. Helsinki, Tammi, 129-139.

6 Suvanto, Antti \& Vesikansa, Jyrki (toim.) 2002. Modernismi taloustieteessä ja talouspolitiikassa. O-ryhmän kirjoituksia ja kirjoituksia O-ryhmästä. Helsinki, Gaudeamus.

7 Koivisto, Mauno 1970. "Vallankumouksellinen ja muu yhteiskuntatiede". Parnasso 2/1970, 78-82. Julkaistu myös teoksessa Väärää politiikkaa, 259-264.

8 Myrdal, Gunnar 1957. Economic Theory and UnderDeveloped Regions. London, Duckworth.

9 Myrdal, Gunnar 1960. Beyond the Welfare State. Economic Planning in the Welfare State and its International Implications. London, Duckworth.

10 Koivisto, Mauno 1968. Ennalta tietäminen ja ennalta määrääminen. Teoksessa Linjan vetoa. Helsinki, Kirjayhtymä 194-201.

11 Pipping, Knut 1947. Kompaniet som sambälle. Iakttagelser $i$ ett finskt frontforband, 1941-1944. Åbo, Åbo Akademi; suomeksi vuonna 1978: Komppania pienoisyhteiskuntana. Sosiologisia havaintoja suomalaisesta rintamayksiköstä 1941-1944. Helsinki, Otava.

12 Koli, Paavo 1955. Ennakkoluuloista teollisessa organisaatiossa. Sosiologinen tutkimus teollisen organisaation johtajiston ja työntekijöiden välisestä vuorovaikutuksesta ja sen eräistä sosiaalisista edellytyksistä. Porvoo, WSOY, 5.

13 Koivisto, Mauno 1956. Sosiaaliset subteet Turun satamassa. Sosiologinen tutkimus. Turun yliopiston julkaisuja B:60. Turku, Turun yliopisto, 187. Ks. myös Bergholm, Tapio 2008. "Oma kokemus tutkimuskohteena - Mauno Koivisto ja Turun satama”. Työelämän tutkimus, 1/2008, 77-81.

14 Allardt, Erik 1964. Yhteiskunnan rakenne ja sosiaalinen paine. Porvoo, WSOY, 144-151.

15 Sundberg, Anneli 1982. "Kansansuosikin kujanjuoksu. Mauno Koivisto etenee kohti presidentin linnaa voihkien vaatimuksille, joiden mukaan hänen on tunnustettava olevansa sosialisti". Helsingin Sanomat, 3.1.1982. Ks. myös Koivisto, Mauno 1994. Kaksi kautta. Muistikuvia ja merkintöjä 1982-1994. Helsinki, Kirjayhtymä, 438-440.

16 Vuoden 1994 valtiopäivät. Pöytäkirjat I. Eduskunta, Helsinki 1995, 17-19 (8.2.1994). Ks. myös Kaksi kautta, 436-437.

17 Sama, 195-197 (1.3.1994). Ks. myös Kaksi kautta, $438-440$. 